\title{
Malignant breast diseases as differential diagnoses in mastitis
}

\section{Maligne Brusterkrankungen als Differenzialdiagnosen von Brustentzündungen}

\author{
Author \\ A. Strauss \\ Affiliation \\ Christian-Albrechts-Universität zu Kiel
}

Key words

- puerperal mastitis

- nonpuerperal mastitis

- breast abscess

- inflammatory breast cancer

- paget's disease

- paraneoplasia

\section{Schlüsselwörter}

- Mastitis puerperalis

- Mastitis non-puerperalis

- Brustabszess

- inflammatorisches Mammakarzinom

- Morbus Paget

- Paraneoplasie

Deutsche Version unter: www:thieme-connect.de/ ejournals/senologie
Bibliography

Dol http://dx.doi.org/

10.1055/s-0042-106077

Senologie 2016; 13: 69-75

(c) Georg Thieme Verlag KG

Stuttgart · New York .

ISSN 1611-6453

\section{Correspondence \\ Univ.-Prof. Dr. med. Alexander \\ Strauss}

Christian-Albrechts-Universität

zu Kiel

astrauss@email.uni-kiel.de

License terms

\section{Zusammenfassung \\ $\nabla$}

Entzündliche Erkrankungen der weiblichen Brust beruhen überwiegend auf bakteriologischen Infektionen des Brustdrüsengewebes. Diese können in ätiologischem wie zeitlichem Zusammenhang mit Geburt und Laktation oder unabhängig vom Wochenbett auftreten. Die lokalen Entzündungserscheinungen bestimmen dabei wesentlich die äußerst schmerzhafte und ggf. mit Allgemeinsymptomen (Fieber) verbundene Symptomatik. In Abgrenzung zu Mastitis und Abszessbildung in der weiblichen Brust können gutartige Hautveränderungen (Erysipel, venöse Thrombose, Sklerodermie, Pannikulitis, Neurodermitis, Allergie, Verletzung), aber auch maligne Erkrankungen (inflammatorisches Mammakarzinom, Morbus Paget, leukämische Infiltration, paraneoplastische Dermatose) ein vergleichbares klinisches Bild verursachen.

Inflammatory changes in the female breast are a group of diseases that can represent a severe symptomatic burden for the women affected, although these conditions are always histologically benign. They mainly result from traumatic lymphogenic or canalicular ascent of bacteria into the mammary gland tissue. Independently of the pathogenesis of the inflammatory process, the severity of the symptoms and their treatment are always exclusively determined by the local findings.

\section{Inflammatory breast diseases $\nabla$}

Puerperal mastitis affects around $1 \%$ of puerperal women. It usually occurs in the second week after birth, so that it typically appears after discharge from hospital [1]. In comparison with multiparous women, primiparae are twice as likely to develop mastritis. Young age and nosocomial conditions facilitate the development of the inflammation,

\section{Abstract \\ $\nabla$}

Inflammatory diseases in the female breast are mainly caused by bacterial infection of the mammary gland tissue. The infections may be etiologically and temporally associated with birth and lactation, or may occur independently of the puerperium. Local inflammatory phenomena are the main factors determining the extremely painful symptoms, which are sometimes associated with general symptoms (fever). Requiring differentiation from mastitis and abscess formation in the female breast, a similar clinical picture may be caused by benign skin changes (erysipelas, venous thrombosis, scleroderma, panniculitis, neurodermatitis, allergy, and trauma) and also malignant diseases (inflammatory breast cancer, paget's disease, leukemic infiltration, and paraneoplastic dermatosis).

which typically - in $80 \%$ of cases - occurs unilaterally.

In terms of its etiopathology, bacterial infection of mammary gland tissue results from the ascent of bacteria along the lactiferous ducts, starting in the area of the maternal nipple - Staphylococcus aureus in $95 \%$ of cases, S. epidermidis $4 \%$, streptococci $3 \%$, Pseudomonas aeruginosa $<1 \%$, and others [2]. Bacterial colonization of the nipple occurs during breastfeeding and originates from the infant's oropharyngeal bacterial reservoir. This is preceded by airborne transmission of the bacterial pathogen to the child - possibly from the mother, medical staff, family members, or visitors. Starting from the bacterially colonized mammilla-areola complex, the pathogen's spread is typically lymphogenic, assisted by rhagades; more rarely, there may be retrograde canalicular spread (with congested lactiferous ducts), or very rarely hematogenous spread [3]. Inadequate hygiene during breastfeeding and/or galactostasis may 
contribute to bacterial propagation and the development of florid infection [2].

Clinically, the classic signs of inflammation - rubor, calor, tumor, and dolor - make the breast appear (unilaterally) red, unusually warm, edematously enlarged, and sensitive to pain. The area of inflammation is most often located in the superior lateral quadrant of the breast. Pathological (purulent) nipple secretion and axillary lymphadenopathy may also be seen ( $\bullet$ Fig. 1 a).

Clinical examination (inspection, palpation) of the local findings is diagnostically indicative. Palpable and enlarged axillary lymph nodes and fever with severe malaise (chills) round out the clinical picture. Bacteriological diagnosis, with or without resistance screening, is usually unnecessary, since Staphylococcus aureus can almost always be identified and since staph. aureus does not developed resistance there are no diagnostic or therapeutic implications [4]. Ultrasonography of the breast can confirm inflammatory edema in the mammary gland tissue, ductal ectasia, and reactive lymph-node enlargement - and above all, it can exclude the formation of abscess cavities ( $\mathbf{F i g}$. 1b).

Puerperal mastitis is treated by systematic drainage of the lactating breast, application of heat with expression (pumping) if needed, as well as analgesic and antipyretic measures. Particularly in the early stage, alternating application of cool compresses can successfully control swelling and reduce symptoms. Antibiotic treatment at this early stage is associated with a risk of microabscesses developing. At more advanced stages of inflammation, it may be necessary to prescribe antibiotics for 7 - 10 days (e. g., penicillinase-resistant penicillin, cephalosporin, clindamycin, macrolides) [2]. If treatment fails (usually due to anti-inflammatory therapy being started too late or administered inconsistently), it may be the first sign of abscess formation. In this case, heat should be applied to support the necrotizing process of the area of inflammation and promote subsequent interventional pus drainage [5]. Weaning is not required, however (prolactin inhibitors are not a routine therapeutic agent), as the neonate often has the same oral bacterial profile (excluding pediatric health impairment due to insufficient bacterial colonization) as is present on the surface of the mother's breast (the degree of comparability after 1 week is $80 \%$ ).

Nonpuerperal mastitis affects approximately $0.1-2 \%$ of all gynecological patients and thus occurs more frequently than the puerperal form ( $\bullet$ Fig. 2a). Sixty percent of these patients are under the age of 30 . Another peak in the incidence occurs during the perimenopause. Recurrences are frequent in spite of appropriate therapy.

In terms of its etiopathology, nonpuerperal mastitis is a mixed bacterial infection of the mammary gland tissue (40\% Staphylococcus aureus, 40\% coagulase-negative staphylococci, 10-20\% anaerobes, < 5\% Escherichia coli, < 5\% Proteus mirabilis, < 5\% enterococci and group B streptococci, lactobacilli, fusobacteria, mycoplasma, and others). It develops via a canalicular or lymphogenic pathway [6]. The following factors promote infection: congested secretions in the efferent ducts near the nipple, hyperprolactinemia (20\%), various medications, endocrine factors, stress, trauma (accidental injury to the breast skin allowing bacterial ingress; animal scratches and bites; and intentional lesions, e.g. with piercing), and last but not least, smoking (60\%, and $90 \%$ with complicated courses - relapse, fistula formation).

Special abacterial forms (granulomatous mastitis, plasma cell mastitis, concomitant or specific forms of mastitis) differ from nonpuerperal mastitis in relation to their pathogenesis and detection, as well as treatment [2].
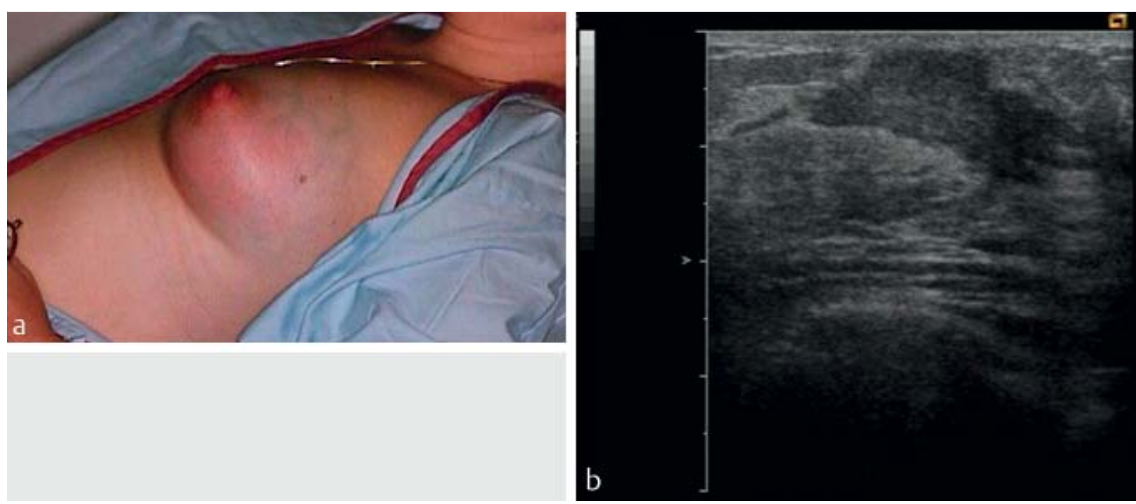

Fig. 1 Puerperal mastitis. a Clinical image with erythema as the cardinal symptom of breast tissue inflammation (courtesy of Prof. Dr. Christoph Mundhenke, Klinik für Gynäkologie und Geburtshilfe UKSH - Campus Kiel). b Ultrasound: Inflammation-mediated structural changes in the gland tissue.
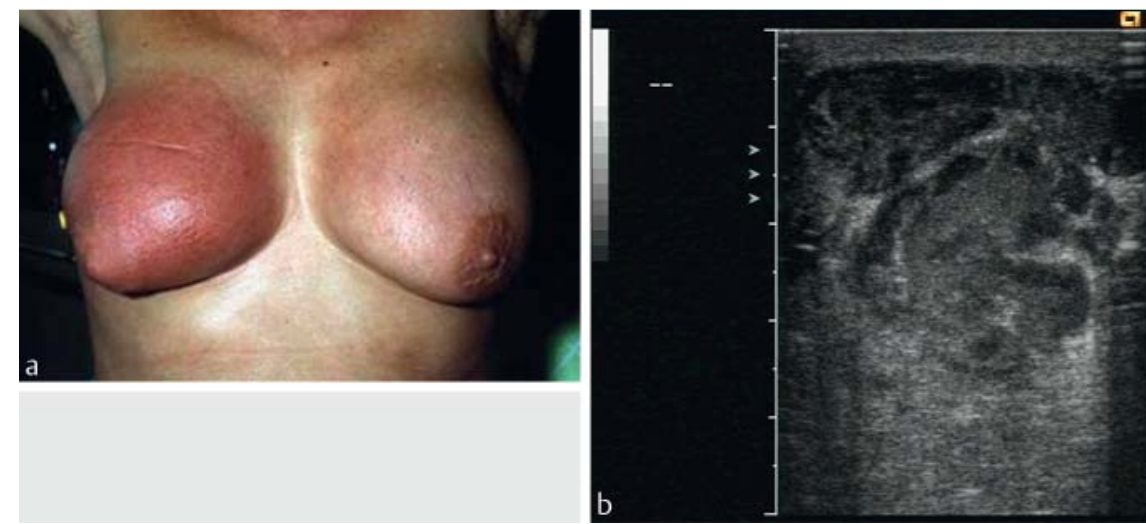

Fig. 2 Nonpuerperal mastitis. a The combined symptoms of tumor, rubor, dolor, and calor in nonpuerperal breast infection (courtesy of Prof. Dr. Christoph Mundhenke, Klinik für Gynäkologie und Geburtshilfe UKSH - Campus Kiel). b Ultrasound: Nonhomogeneous swelling and hypoechoic areas with edema in the inflamed adipose tissue. 
Clinically, an area of nonpuerperal inflammation is usually unilateral and located near the nipple. A gradual decline in local symptoms, associated with moderate fever, malaise, and altered laboratory test values typical for infection are diagnostically indicative in comparison with puerperal mastitis. In nonpuerperal mastitis, a lactiferous duct fistula that developed at the time of the original illness can render the mammary gland tissue permanently prone to infection and result in a protracted course with chronic recurrences, and among other things may make it extremely difficult to pinpoint the exact cause [7].

Granulomatous mastitis results from a retained secretion that infiltrates the breast stroma from a damaged duct, causing periductal changes consistent with plasma cell mastitis. Microabscesses lead to the development of tissue granulation. Long-term corticosteroid administration is used to treat the condition. Surgery and biopsy procedures are associated with a risk of exacerbating the disease and should therefore be avoided.

The diagnostic approach with nonpuerperal mastitis is the same as that with the puerperal form. Ultrasound ( 0 Fig. $\mathbf{2 b}$ ) and laboratory tests (previously unnoticed hyperprolactinemia is seen in $20 \%$ of cases) supplement the clinical assessment. However, clearly raised parameters for inflammation (leukocytes, CRP) are only seen in advanced processes (such as abscess). When the pathogenesis of the mastitis is nonpuerperal, the results of bacteriological analyses of nipple secretion or (abscess) pus, including bacterial resistance screening, may potentially determine the therapeutic approach.

Treatment for early-stage nonpuerperal mastitis is based on systemic antibiotic administration including the anaerobic spectrum, which can be adjusted if necessary after resistance screening. Supplementary symptomatic and resorptive treatment measures (including cooling of the breast) should be initiated. Depending on the etiology of the inflammation, a prolactin inhibitor can be added to the drug treatment in selected cases. Prolactin inhibitors can reduce recurrences by $10 \%$ [2]. Fistulas that develop in complicated courses of mastitis should be surgically excised along with the lactiferous duct involved (this can often be demonstrated using ultrasound). Despite initially successful treatment, however, courses involving recurrences are not uncommon. Particularly from this point of view, adequate treatment compliance (to achieve a sustained response) should be ensured.

Breast abscess, as a sequela of mastitis, also occurs unilaterally like the initial infection - with a ratio of nonpuerperal to puerperal abscesses of $55 \%$ to $45 \%$. The risk factors correspond to those of the underlying forms of mastitis. Depending on the etiology, recurrences are possible despite appropriate treatment. In terms of the etiopathogenesis, abscesses form when mastitis progresses unabated (due to a lack of treatment or failure of treatment), leading to local encapsulation and proteolytic and purulent necrotizing processes [8].

Diagnostically, breast abscesses can be detected using inspection (swelling, reddening of the skin, peau d'orange, pathologic secretion), palpation (fluctuation, hyperthermia, pronounced pain, ipsilateral axillary lymphadenopathy), fever (late in the course of the disease), laboratory tests (for inflammation parameters) and breast ultrasonography $[9,10]$. For breast abscesses, ultrasound imaging not only offers early visualization and localization of even small accumulations of pus, it also allows differential-diagnostic distinction between abscesses and inflammations that do not form abscesses, as well as tumors in the mammary gland tissue. Sonographically, the abscess cavity appears as a sharply defined lesion with smooth borders surrounded by a thick, hyperechoic abscess membrane, filled with hypoechoic, homogeneous internal echoes ( $\odot$ Fig. 3, 4a, b) [4].

From the clinical point of view breast abscess is a condition that is extremely painful for the patient and is only secondarily associated with general symptoms [11].

With regard to treatment, breast abscesses have been treated since the time of Hippocrates ( "ubi pus, ibi evacua") with surgical lancing (incision and counterincision) ( $\bullet$ Fig. 5) [12]. As an alternative to open surgical intervention - invasive procedures involving general anesthesia, pain, and scarring ( $\bullet$ Fig. 6 ) - technological advances in high-resolution ultrasound of the breast that go beyond the diagnostic aspect now allow minimally invasive approaches to abscess therapy. The reduced invasiveness, the need for only local anesthesia, the outpatient nature of the procedure, the lack of scarring, lower recurrence rate, ability to continue breastfeeding at home, reduced need for analgesic medication, a

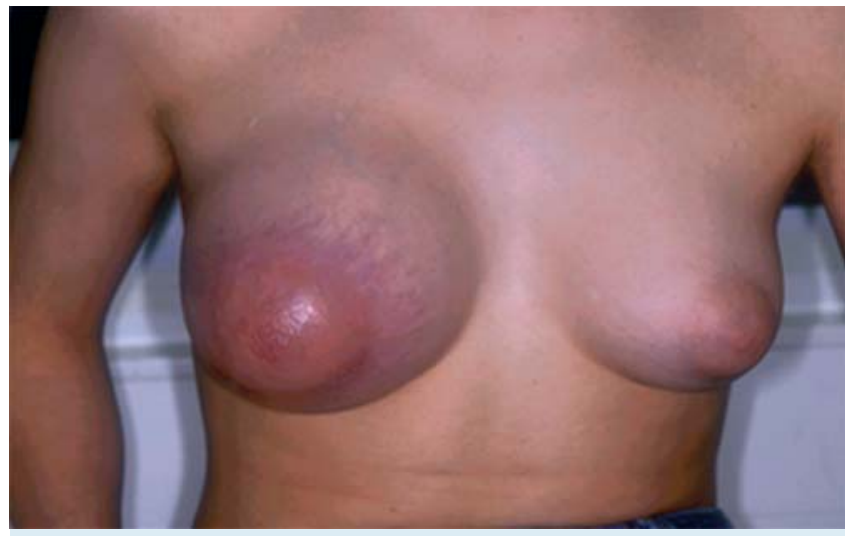

Fig. 3 Clinical appearance of an extensive right-sided nonpuerperal breast abscess: swelling, reddening of the skin, hyperthermia, and extreme pain.
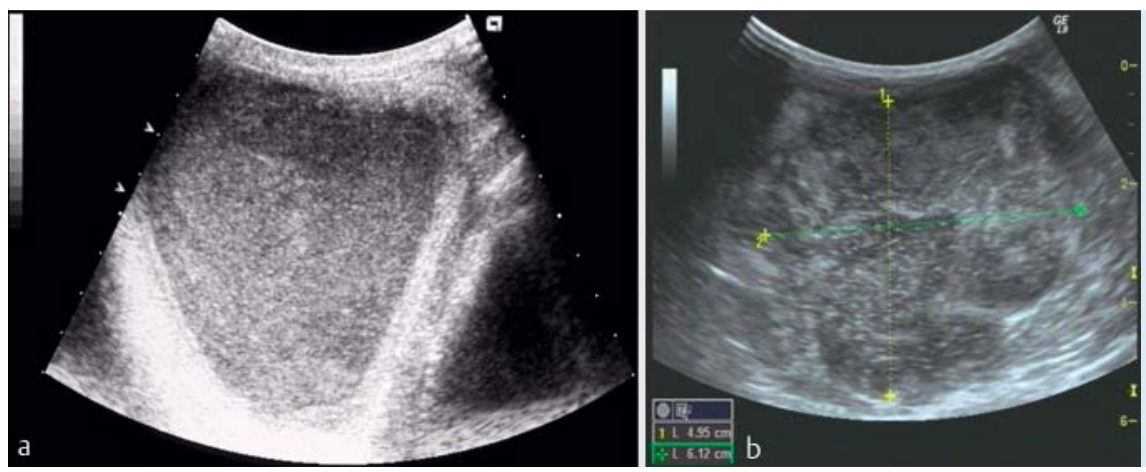

Fig. 4 Ultrasound appearance of nonpuerperal breast abscesses. a A smoothly circumscribed mass with a hyperechoic rim (abscess capsule), filled with homogeneous hypoechoic internal echoes indicating an accumulation of pus (abscess cavity). The ultrasound findings correspond to the clinical appearance shown in Fig. 3. b A multilocular breast abscess marked by septation and nonhomogeneous internal echoes in the individual compartments of the abscess cavity. 
look off effects on breastfeeding in subsequent pregnancies, along with benefits in terms of health-care costs, all mean that there is a high level of patient satisfaction with this approach ( $\bullet$ Fig.7a-d) [11-16]. If conservative antibiotic treatment for mastitis fails, local application of heat (moist heat, shortwave, microwave) promotes encapsulation of the inflammation and thus makes the abscess treatable using drainage [8]. Contraindications to this minimally invasive approach include a strong suspicion of inflammatory breast cancer, a granulomatous pathogenesis for the abscess, a highly septate and very large abscess

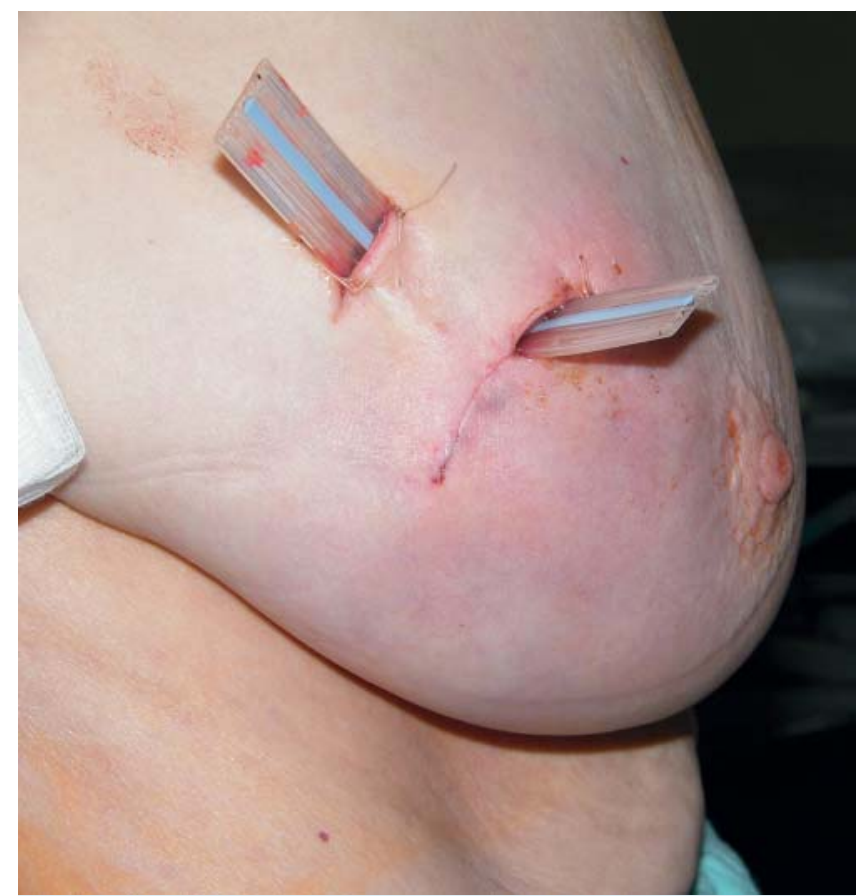

Fig. 5 Principle of surgical treatment for a breast abscess: broad incision and counterincision with wick insertion. (relative contraindication), as well as highly viscous abscess contents (relative contraindication).

\section{Malignant diseases as differential diagnoses}

$\nabla$

Requiring differentiation from inflammatory breast diseases, a similar clinical picture to that of breast inflammation/abscess may be caused by benign skin changes such as erysipelas, venous thrombosis, scleroderma, panniculitis, neurodermatitis and allergic skin reactions due to mechanical, physical, medicinal, and toxic exogenous tissue changes (due to jewelry, piercing, manipulation, injury, temperature, cream, bra) ( $\bullet$ Fig. 8), as well as malignant diseases $[4,17,18]$.

Inflammatory breast cancer

$>$ Paget's disease

Leukemic infiltration

$>$ Paraneoplastic dermatoses

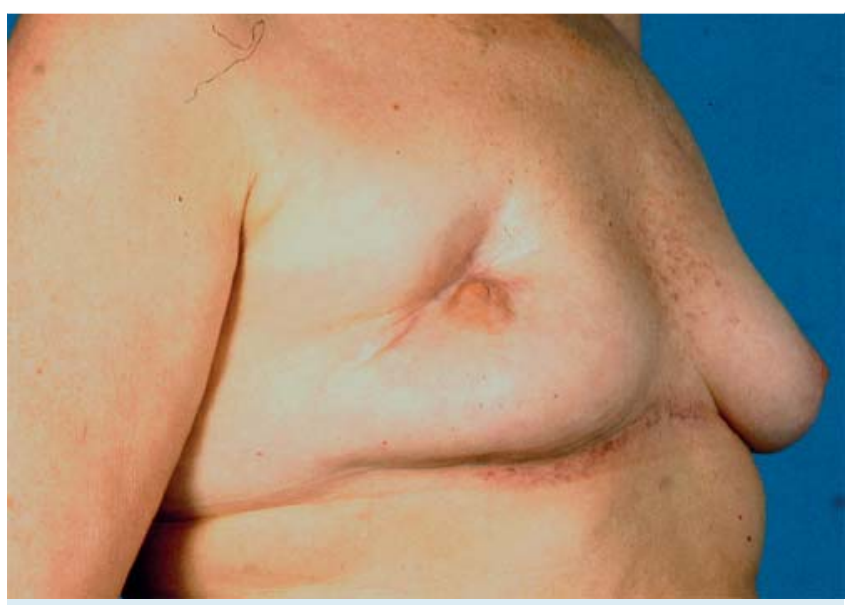

Fig. 6 Cosmetically poor long-term result of surgical breast abscess treatment.
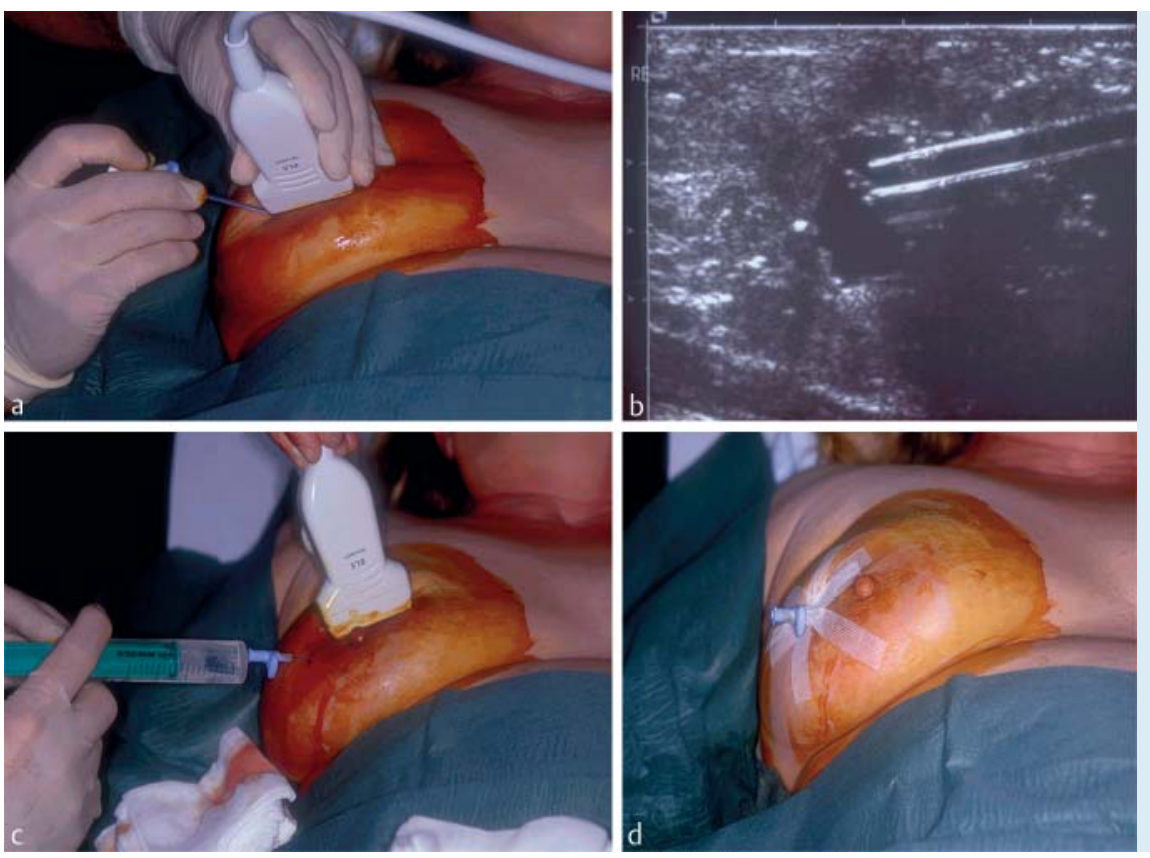

Fig. 7 The technique for minimally invasive breast abscess drainage. a Ultrasound-guided puncture of the abscess with an indwelling venous catheter. The cutaneous puncture site is selected at the edge of the nipple-areola complex for cosmetic reasons. $\mathbf{b}$ Ultrasound localization of the abscess cavity, into which the drainage catheter is inserted. c Irrigation of the abscess to drain/liquefy the purulence. $\mathbf{d}$ Atraumatic attachment of the (plastic) drainage catheter to the breast using Steri-Strip ${ }^{\circledR}$. The catheter is left in place for longer-term drainage (and to allow repeated wound irrigation if needed). 


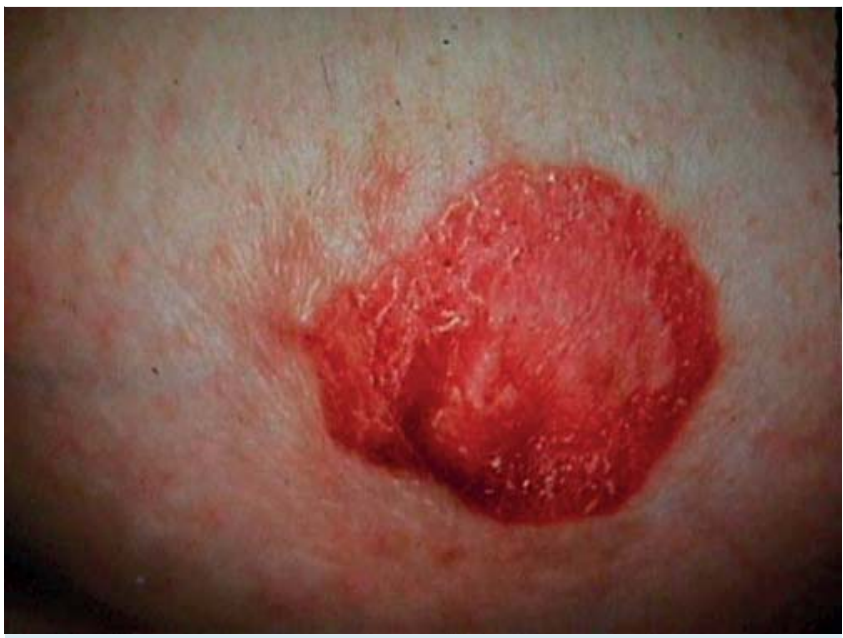

Fig. 8 Nipple eczema. This is a benign differential diagnosis for nonpuerperal mastitis and also for inflammatory carcinoma (courtesy of Prof. Dr. Christoph Mundhenke, Klinik für Gynäkologie und Geburtshilfe UKSH Campus Kiel).

Carcinoma of the breast is the most frequent type of malignancy and cause of death due to cancer among women in Germany. Inflammatory breast cancer is not defined as a distinct histological variant, but is recognized on the basis of visually and palpably diffuse and irregularly delimited erythema. With an incidence of $1-6 \%$ of all breast cancer cases in the industrialized countries, the inflammatory form of breast cancer represents only a small proportion of newly diagnosed cases. The patients' median age is between 47 and 57 years [19]. The prognosis is poor. The 5year survival rate with inflammatory carcinoma is only $30-$ $50 \%$, in comparison with an average of $86-90 \%$ for patients with all types of breast cancer [20].

Diagnostically, inspection and palpation are particularly important for guidance in this tumor entity, as in other malignant clinical pictures in the female breast as well. The clinical appearance - with infiltrated and indurated skin (peau d'orange) that is extremely painful, sometimes with nodular ulcerations, edematous swelling, hyperthermic and reddened - provides a single-glance diagnostic criterion. Underlying fluctuations are not always present, but may occur in advanced stages. In more than half of the cases, it is not possible to distinguish an actual nodular tumor beyond the extensive/squamous area of altered skin. Since the clinical appearance (breast reddening) on its own is not sufficient to establish an unequivocal diagnosis of the inflammatory form of breast cancer ( $\bullet$ Fig. 9), histological confirmation (with an open skin biopsy or punch biopsy) must be regarded as indispensable, particularly in view of the need to distinguish it from inflammatory changes in the breast. In addition, early axillary lymph-node involvement (which is present in $90 \%$ of cases at the time of the initial diagnosis), which is associated with a poor prognosis, is easily assessed using both palpation and ultrasound. Mammography has much less diagnostic value with cutaneous inflammatory variants than in other forms of breast cancer [21].

Clinically, the cutaneous "inflammation" spreads very rapidly and without clear borders in the form of lymphangitic carcinomatosis of the breast skin (lymphangiosis/neoplastic vascular invasion, usually of the invasive ductal growth type). This is partly responsible for the unfavorable prognosis in this type of carcino-

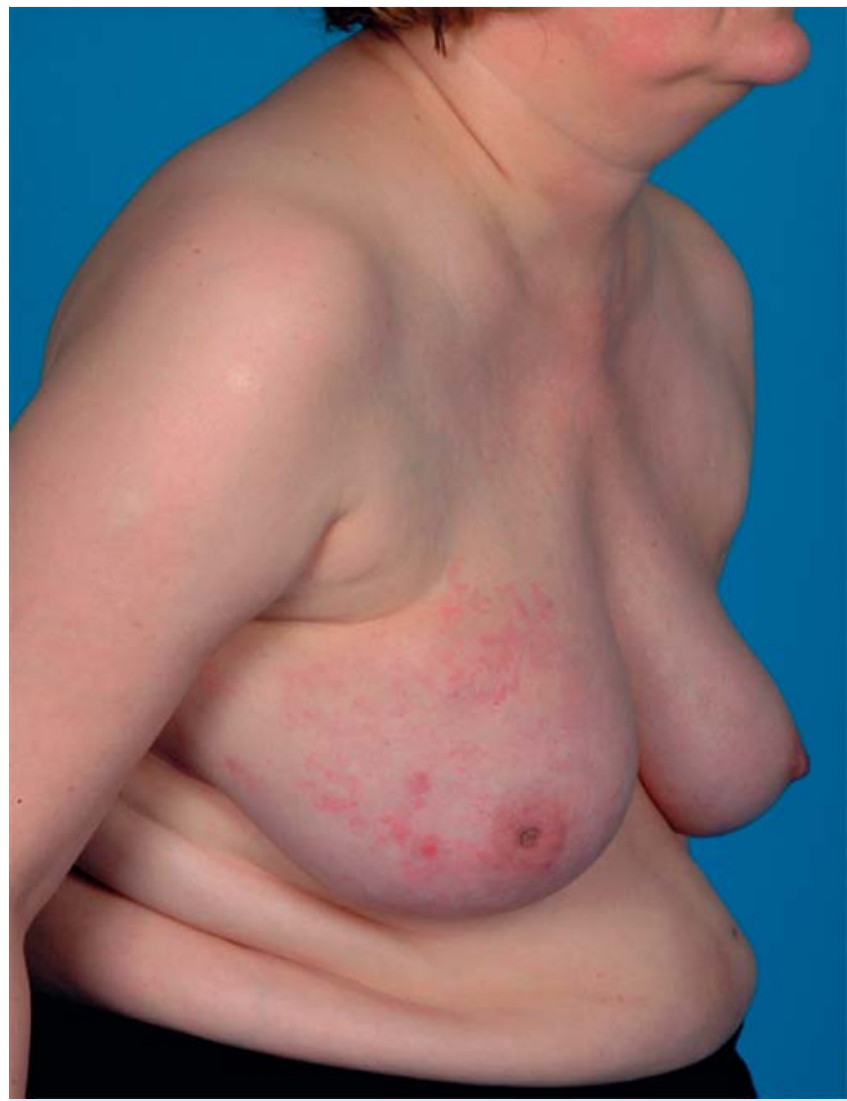

Fig.9 Inflammatory breast carcinoma. There is multicentric, partly confluent erythema over more than two quadrants of the right breast, caused by lymphangiosis carcinomatosa.

ma. The inferior quadrants of the breast are more often affected, and nipple retraction frequently occurs.

Treatment involves primary systemic chemotherapy (including anthracyclines and taxanes), followed if necessary by modified radical mastectomy, adjuvant cytostatic drugs, and radiotherapy of the thoracic wall (for local tumor control as there is strong or early risk of local or regional recurrence). Long-term endocrine treatment approaches are appropriate for some patients. Response rates of up to $80 \%$ can be achieved using multimodal therapeutic. However, not least because distant metastases occur at an early stage, inflammatory breast cancer regimes has the poorest prognosis of all types of primary breast cancer [22].

Paget's disease of the breast is a special intradermal manifestation of an intraductal, noninvasive (in approximately $66 \%$ of cases) or infiltrating ductal breast carcinoma in which the nipple and the surrounding skin are infiltrated. Paget's disease occurs in approximately $2 \%$ of all breast cancer patients.

Clinically, the barrier function of the affected skin is altered, leading to the secretion of serous exudate. This leads to the nipple and its surroundings becoming reddened and covered with a moist, crusting layer. Skin thickening, edema, nipple inversion, and inflammatory changes in the areola and periareolar skin may occur. These changes cause little or no pain ( $\mathbf{F i g}$. 10).

For diagnosis, reddened, eczematous, and sometimes even ulcerative changes in the skin of the nipple (with an encrusted, scaly, brownish-red skin surface) initially indicate the disease. When these symptoms are present and in all cases in which there is evidence of paget cells in the skin of the nipple, it can be assumed 


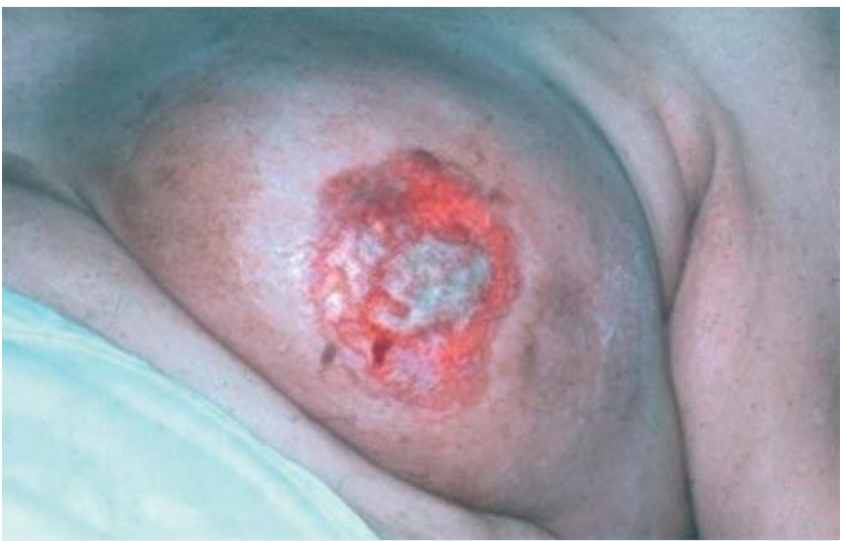

Fig. 10 Paget's disease. There is eczematous, purulent ulceration of the nipple, as clinical correlate of a paget's carcinoma developing intraductally and intradermally (courtesy of Prof. Dr. Christoph Mundhenke, Klinik für Gynäkologie und Geburtshilfe UKSH - Campus Kiel).

that there is intraductal or infiltrating ductal paget's disease underlying the clinical picture.

For treatment, the approach used in paget's carcinoma does not differ from that for intraductal or primarily invasive ductal breast cancer (surgical: including resection of the nipple). The option for preserving the breast depends on the extent of the intraductal involvement. Radiotherapy, endocrine treatment, and cytostatic therapy if needed can supplement the therapeutic concept. The occurrence of paget's symptoms does not worsen the overall prognosis of the disease. The characteristics of the underlying carcinoma are the decisive aspect.

Erythemas of the female breast due to leukemic infiltration occur only rarely, as do paraneoplastic dermatoses - erythema gyratum repens, acquired hypertrichosis lanuginosa (obligate) or dermatomyositis, subacute cutaneous lupus erythematosus (facultative). The classification of paraneoplasias as obligate or facultative expresses the degree of their association with the specific underlying malignancy in each case - 100\% in comparison with $3-30 \%$.

Diagnostically, the paraneoplastic association of malignancy with polymorphous skin changes (reddening, swelling) and the imaging appearance (ultrasound: homogeneous, hypoechoic, microlobulated, poorly defined, hypervascularized) indicates the specific pathogenesis of these forms of disease. On the other hand, these signs can also be misleading. Itching is noted as a nonspecific but frequent symptom, even without changes yet being visible on the skin [23].

\section{Differential-diagnostic algorithm}

Due to the various ways in which inflammatory breast diseases can be confused with malignancies of the breast, accurate clinical differentiation is sometimes difficult and is only possible with a precise awareness of the different clinical pictures. A multimodal approach should therefore be used, particularly in patients in which the clinical findings are ambiguous ( $\bullet$ Table 1 ).
Table 1 Differential-diagnostic algorithm.

\begin{tabular}{|c|c|c|c|}
\hline & $\begin{array}{l}\text { bacterial } \\
\text { breast inflam- } \\
\text { mation }\end{array}$ & $\begin{array}{l}\text { (inflammatory) } \\
\text { malignancy }\end{array}$ & $\begin{array}{l}\text { paget's } \\
\text { disease }\end{array}$ \\
\hline \multicolumn{4}{|l|}{ clinical manifestations } \\
\hline $\begin{array}{l}\text { early stage (skin red- } \\
\text { dening, possibly local } \\
\text { scaly findings on nip- } \\
\text { ple) }\end{array}$ & ++ & + & + \\
\hline $\begin{array}{l}\text { chronic disease (skin } \\
\text { reddening, possibly ec- } \\
\text { zematous, crusty, ul- } \\
\text { cerative, brownish-red } \\
\text { skin surface) }\end{array}$ & + & $\begin{array}{l}++ \\
\text { (increasing red- } \\
\text { dening, indura- } \\
\text { tion) }\end{array}$ & ++ \\
\hline mamillary secretion & ++ & + & + \\
\hline \multicolumn{4}{|l|}{ laboratory tests } \\
\hline $\begin{array}{l}\text { inflammation param- } \\
\text { eters (incl. leukocytes, } \\
\text { CRP) }\end{array}$ & ++ & $\begin{array}{l}\text { - } \\
\text { (nonspecific } \\
\text { changes at most) }\end{array}$ & $\begin{array}{l}- \\
\text { (nonspeci- } \\
\text { fic changes } \\
\text { at most) }\end{array}$ \\
\hline $\begin{array}{l}\text { tumor markers (incl. } \\
\text { CA-15-3, CEA) }\end{array}$ & - & $\begin{array}{l} \pm \\
\text { (sometimes possi- } \\
\text { ble) }\end{array}$ & - \\
\hline $\begin{array}{l}\text { microbe detection } \\
\text { (bacteriological diag- } \\
\text { nosis) }\end{array}$ & $\begin{array}{l}++ \\
\text { (or possible) }\end{array}$ & - & - \\
\hline \multicolumn{4}{|l|}{ imaging findings } \\
\hline breast ultrasound & ++ & ++ & + \\
\hline mammography & $\pm(-)$ & ++ & + \\
\hline MRI [24] & + & ++ & ++ \\
\hline digital tomosynthesis & - & + & - \\
\hline elastography & - & + & - \\
\hline \multicolumn{4}{|c|}{ treatment response ( 7 - 14 days) } \\
\hline $\begin{array}{l}\text { symptoms improve } \\
\text { with anti-inflammatory } \\
\text { measures (systemic an- } \\
\text { tibiotics, physical, and } \\
\text { surgical) following clin- } \\
\text { ical suspicion of non- } \\
\text { puerperal/puerperal } \\
\text { mastitis/breast abscess }\end{array}$ & $\begin{array}{l}++ \\
\text { (if initiated in } \\
\text { time and admi- } \\
\text { nistered consis- } \\
\text { tently) }\end{array}$ & $\begin{array}{l}- \text {-, sometimes } \pm \\
\text { (apparent effect } \\
\text { mainly due to } \\
\text { physical measures } \\
\text { and diagnostic } \\
\text { bias) }\end{array}$ & - \\
\hline \multicolumn{4}{|l|}{ special abacterial forms } \\
\hline & $\begin{array}{l}\text { granulomatous } \\
\text { mastitis, plas- } \\
\text { ma cell masti- } \\
\text { tis, concomi- } \\
\text { tant mastitis, } \\
\text { specific masti- } \\
\text { tis }\end{array}$ & & \\
\hline $\begin{array}{l}\text { microbe detection } \\
\text { (bacteriological diag- } \\
\text { nosis) }\end{array}$ & - & - & - \\
\hline \multirow{2}{*}{$\begin{array}{l}\text { response to antibiotic } \\
\text { therapy }\end{array}$} & $-( \pm)$ & - & - \\
\hline & $\begin{array}{l}\text { lactiferous duct } \\
\text { fistula }\end{array}$ & & \\
\hline $\begin{array}{l}\text { chronic, recurrent } \\
\text { disease }\end{array}$ & $\begin{array}{l}++ \\
\text { (relapses not } \\
\text { uncommon de- } \\
\text { spite initially } \\
\text { successful } \\
\text { treatment. } \\
\text { Good compli- } \\
\text { ance decisive) }\end{array}$ & $\begin{array}{l}++ \\
\text { (possible primary } \\
\text { progression) }\end{array}$ & $\begin{array}{l}++ \\
\text { (possible } \\
\text { primary } \\
\text { progres- } \\
\text { sion) }\end{array}$ \\
\hline
\end{tabular}




\section{References}

1 Peters F. Brustentzündungen im Wochenbett - Puerperale Mastitis: Empfehlungen für Diagnostik und Therapie. Senologie - Zeitschrift für Mammadiagnostik und -therapie 2009; 6 (4): 227-230

2 Marchant DJ. Inflammation of the breast. Obstet Gynecol Clin North Am 2002; 29 (1): 89-102

3 Hayes R, Michell M, Nunnerley HB. Acute inflammation of the breast the role of breast ultrasound in diagnosis and management. Clin Radiology 1991; 44 (4): $253-256$

4 Strauss A. Entzündliche Brusterkrankungen in Ultraschallpraxis, Geburtshilfe und Gynäkologie. III. vollständig überarbeitete Auflage. Hrsg. Strauss A. unter Mitarbeit von Müller-Egloff S. Müller T. Heidelberg: Springer Verlag; 2016

5 Kahlert S, Bauerfeind I, Strauss A et al. Behandlung des Mammakarzinoms in der Schwangerschaft - Erfahrungen aus der Universitätsfrauenklinik Großhadern und Internationale Datenlage. Zentralblatt Gynäkologie 2004; 126 (3): 159-166

6 Eryilmaz R, Sahin M, Hakan Tekelioglu M et al. Management of lactational breast abscesses. Breast 2005; 14 (5): 375-379

7 Strauss A, Middendorf K, Müller-Egloff S et al. Sonografisch gesteuerte Mammaabszesspunktion als minimal-invasive Alternative zur chirurgischen Inzision. Ultraschall in der Medizin 2003; 24: 393 - 398

8 Berghof S, Peters F. Empfehlungen einer Arbeitsgruppe der deutschen Gesellschaft für Senologie - Die non-puerperale Mastitis. Senologie Zeitschrift für Mammadiagnostik und -therapie 2008; 5 (1): 27 - 31

9 Ulitzsch D, Nyman MK, Carlson RA. Breast abscess in lactating women: US-guided treatment. Radiology 2004; 232 (3): 904-909

10 Hansen PB, Axelsson CK. Treatment of breast abscess. An analysis of patient material and implementation of recommendations. Ugeskr Laeger 2003; 165 (2): 128-131

11 Christensen AF, Al-Suliman N, Nielsen KR et al. Ultrasound-guided drainage of breast abscesses: results in 151 patients. British Journal of Radiology 2005; 78 (927): 186 - 188
12 Strauss A, Middendorf K, Müller-Egloff S et al. Der Brustabszess - Inzision und Gegeninzision noch zeitgemäß? Gyn - Praktische Gynäkologie 2005; 10: $218-227$

13 Middendorf K, Müller-Egloff S, Heer IM et al. Sonografisch gesteuerte Mammaabszesspunktion als minimal-invasive Alternative zur chirurgischen Inzision. Onkologie 2003; 26 (Suppl 2): 61

14 Karstrup S, Solvig J, Nolsoe CP et al. Acute puerperal breast abscesses: US-guided drainage. Radiology 1993; 188 (3): 807 -809

15 Garg P, Rathee SK, Lal A. Ultrasonically guided percutaneous drainage of breast abscess. Indian Medical Association 1997; 95 (11): 584-585

16 Strauss A, Heer IM, Müller-Egloff S et al. Abszesse der weiblichen Brust ein therapeutischer Paradigmenwechsel. Senologie 2006; 3: 57-64

17 Strauss A, Sanders L. Minimalinvasive Mammaabszessbehandlung - ein Paradigmenwechsel. Speculum - Zeitschrift für Gynäkologie und Geburtshilfe 2010; 28 (3): 6-11

18 Jacobs A, Abou-Dakn M, Becker K et al. S3-Leitlinie „Therapie entzündlicher Brusterkrankungen in der Stillzeit" AWMF Leitlinien-Register Nr. 015/071. Geburtshilfe und Frauenheilkunde 2013; 73: 1202 - 1208

19 Harris EE, Schultz D, Bertsch $H$ et al. Ten-year outcome after combined modality therapy for inflammatory breast cancer. Int J Radiat Oncol Biol Phys 2003; 55 (5): 1200-1208

20 Hance KW, Anderson WF, Devesa SS et al. Trends in inflammatory breast carcinoma incidence and survival: the surveillance, epidemiology, and end results program at the National Cancer Institute. J Natl Cancer Inst 2005; 97 (13): 966 - 975

21 Liauw SL, Benda RK, Morris CG et al. Inflammatory breast carcinoma: outcomes with trimodality therapy for nonmetastatic disease. Cancer 2004; 100 (5): $920-928$

22 S3-Leitlinie „Mammakarzinom der Frau; Diagnostik, Therapie und Nachsorge“. AWMF Leitlinien-Register 032/045. 2012

23 Schad K, Cozzio A. Paraneoplasien in Derma Net online. BBS Hrsg. Schöfer H., Baur-Beger S. Verlag Wiesbaden 2014

24 Lee KW, Chung SY, Yang I et al. Inflammatory breast cancer: imaging findings. Clin Imaging 2005; 29 (1): $22-25$ 